\title{
Optimum conditions for Inulinase production by Aspergillus niger using solid state fermentation
}

\author{
Zainab W. Abdulameer* $\quad$ Bahaa N. Essa** \\ Received 26, January, 2014 \\ Accepted 29, May, 2014
}

Ghazi M. Aziz*

NoDerivatives 4.0 International Licens

\section{Abstract:}

Thirty local fungal isolates according to Aspergillus niger were screened for Inulinase production on synthetic solid medium depending on inulin hydrolysis appear as clear zone around fungal colony. Semi-quantitative screening was performed to select the most efficient isolate for inulinase production. the most efficient isolate was AN20. The optimum condition for enzyme production from $A$. niger isolate was determined by busing a medium composed of sugar cane moisten with corn steep liquor 5;5 (v/w) at initial $\mathrm{pH} 5.0$ for 96 hours at $30{ }^{0} \mathrm{C}$. Enzyme productivity was tested for each of the yeast Kluyveromyces marxianus, the fungus $A$. niger AN20 and for a mixed culture of $A$. niger and $K$. marxianus. The productivity of $A$. niger gave the highest specific activity of $153 \mathrm{U} / \mathrm{mg}$, as compared with $K$. marxianus which gave $86 \mathrm{U} / \mathrm{mg}$.

Key words: Inulinase , Aspergillus niger; Kluyveromyces marxianus

\section{Introduction:}

Inulinase are enzymes that degrade the $\beta-(2,1)$ linkages of $\beta$ fructans, like inulin. Inulinase are classified into endo- and exoInulinases, depending on their mode of action. They act by using two mechanism: exo-inulinases (EC 3.2.1.80) sequentially split-off the terminal $\quad \beta-(2,1) \quad$ fructofuranosidic bonds, while endo-inulinases hydrolyze (EC 3.2.1.7) the internal linkages in inulin and release inulooligosaccharides. Inulinases are produced from several fungal species [1]. The genus Aspergillus is one of the most important filamentous fungal genera. Aspergillus species are used in the fermentation industry, but they are also responsible of various plant and food secondary rot [2]. Aspergillus niger is a soil saprobe with a wide array of hydrolytic and oxidative enzymes involved in the breakdown of plant lignocellulose. A variety of these

* Department of Biotechnology, College of Science, University of Baghdad.

** Department of Scientific Affairs, University of Baghdad. enzymes from $A$. niger is important in the biotechnology industry [3]. Production of inulinase by fermentation which is a method of generating enzymes for industrial purposes. Fermentation involves the use of microorganisms, like bacteria and yeast to produce the enzymes. There are two methods of fermentation used to produce enzymes. These are submerged fermentation and solid-state fermentation (SSF) [4]. The production of enzymes by SSF has gained much attention in biotechnology studies for production of lipases, inulinase, proteases, etc. The use of low cost residues, higher productivities, low energy requirements, lower waste water prouction, extended stability of products and low production costs are some of the main advantages of SSF inulinase from Aspergillus niger [5]. 


\section{Materials and Methods:}

Chemicals: Potato-dextrose agar (PDA) was obtained from hi-medias, other chemicals were supplied by BDH Chemicals. Thirty local fungal isolates according to Aspergillus. niger were screened for inulinase production on synthetic solid medium depending on inulin hydrolysis appear as clear zone around fungal colony.

\section{Fungal isolates:}

Thirty fungal isolates according to $A$. niger were collected from different sources, 7 isolates from College of Science /Baghdad University, 3 isolates from College of Science for women / Baghdad University, 11 isolates from College of Science /AlMustansarya University, 4 isolates from Ibn-Alhaitham college/ Baghdad University, 3 isolates from Agriculture College/ Baghdad University and 2 isolates from College of Science / Babylon University. Three Kluyveromyces isolates were obtained from College of Science /Baghdad University, All isolates were sub cultured each two weeks on Potato Dextrose Agar (PDA) and incubated at $30{ }^{0} \mathrm{C}$.

Semi-quantitative screening of inulinase producing isolates:

Isolates efficiency for inulinase production was screened according to the method described by Kumar et al. [6]. The screening was performed by culturing fragments of the collected isolates in the holes of the prepared medium, the holes were prepared by using $3 \mathrm{~mm}$ cork-borer after sterilization with alcohol and flame and transfer the fragment under sterilized condition by loop to the surface of the plates containing the synthetic medium containing $\mathrm{gm} / \mathrm{L}$ (Agar :20, $\left(\mathrm{NH}_{4}\right)_{2} \mathrm{SO}_{4}: 0.5, \mathrm{KH}_{2} \mathrm{PO}_{4}: 3$, $\mathrm{NaNO}_{3}: 1.5, \quad \mathrm{MgSO}_{4} .7 \mathrm{H}_{2} \mathrm{O}: 0.01$, Inulin:3). After 48 hours of incubation at $30^{\circ} \mathrm{C}$, a clear zone appeared around each colony as a sign of inulinase production, the clearance zone ratios were measured, and the colony with the higher ratio was selected as the most effective isolate in inulinase production.

\section{Enzyme Production:}

Five $\mathrm{ml}$ of corn steep liquor (pH 5) was added to $5 \mathrm{gm}$ of carbon source powder in 250 erlenmyer flask, then the medium was sterilized by autoclaving at $121^{\circ} \mathrm{C}$ for $15 \mathrm{Min}$. One $\mathrm{ml}$ of selected $A$. niger suspension $10^{6}$ spore/ $\mathrm{ml}$ was inoculated into each flask and incubated at $30^{\circ} \mathrm{C}$ for four days. After incubation time, $50 \mathrm{ml}$ of $0.1 \mathrm{M}$ sodium acetate $\mathrm{pH} 4.8$ was added to each flask, and $150 \mathrm{rpm}$ for enzyme extraction, then the extract was filtrated by No. 1 Whitman filter paper. The filtrate considered crude enzyme, then the enzyme activity and protein concentration were estimated.

Estimation of inulinase Activity and concentration: Inulinase activity was estimated in solutions resulted after extraction of the enzyme by sodium acetate $\mathrm{pH} 4.8$, by the method described by Miller which depends on inulinase analysis (substrate concentration (inulin) $1 \%$ in sodium acetate) to the reduced sugars formed by enzyme activity. Unit of enzyme activity is defined as the amount of enzyme necessary to liberate $1 \mathrm{mM}$ of Fructose in one minute in standard conditions. Protein concentration was estimated according to the method described by Bradford depending on Bovine serum albumins standard curve and using of coomassiee blue G-250 and measured at $595 \mathrm{~nm}[7,8]$.

\section{Optimization for Inulinase Production:}

Many factors that influence inulinase production from selected $A$. niger had been studied, these factors included type of carbon source, moisturizing solution, moisture ratio, initial $\mathrm{pH}$ of the medium and the incubation temperature, period of incubation. 
Optimum carbon source: Four carbon sources were tested to determine the optimum carbon source for inulinase production from selected isolate, these sources were leek, onion, garlic and sugar cane. All sources were washed with tab water then sliced to small pieces and dried. These dried parts were grinded until they became powder.

\section{Moisturizing solution:}

Three different moisturizing solutions with different nitrogen sources were examined to determine the best solution for inulinase production from selected A. niger, these solutions that described by Skowronek and Fidurek [9] are:

A. Yeast extract $(0.0144 \mathrm{gm}), \mathrm{MnSO}_{4}$ (0.166 gm), $\mathrm{K}_{2} \mathrm{HPO}_{4}(0.021 \mathrm{gm})$, and corn steep liquor.

B. $\mathrm{NH}_{4} \mathrm{NO}_{3}(0.0318 \mathrm{gm}), \mathrm{MnSO}_{4}$ (0.130 gm), Soya been (0.303 gm), $\mathrm{K}_{2} \mathrm{HPO}_{4}(0.0262 \mathrm{gm})$ and Distilled water.

C. Corn steep liquor and Distilled water used as control treatment.

$5 \mathrm{ml}$ of each solution was added separately to $5 \mathrm{gm}$ of sugar cane in 250 $\mathrm{ml}$ flask, and inoculated with A. niger $10^{6} \mathrm{spore} / \mathrm{ml}$, then incubated at $30^{\circ} \mathrm{C}$ for four days.

Moisture ratio:

Five gram of sugar cane was moisten with different volumes of corn steep liquor containing (Yeast extract, $\mathrm{MnSO}_{4}$ and $\mathrm{K}_{2} \mathrm{HPO}_{4}$ ). Different moisture ratios were tested 5:5, 5:10, $5: 15,5: 20(\mathrm{w} / \mathrm{v})$ to select the optimum moisture for inulinase production.

\section{Optimum pH:}

Production media was distributed into flasks, the $\mathrm{pH}$ of moisturizing solution was then adjusted to 4, 5, 6, 7, 8, 9 and then inoculated with $A$. niger, it was then incubated at $30{ }^{\circ} \mathrm{C}$ for 4 days. The inulinase activity was determined after incubation to determine the optimum $\mathrm{pH}$ for inulinase production.
Incubation temperature and period:

The culture which consists of the medium contained on sugar cane (5 $\mathrm{gm})$, corn steep liquor $(5 \mathrm{ml})$ and $\mathrm{pH}$ 5.0 , inoculated with $10^{6}$ spores $/ \mathrm{ml}$ of selected $A$. niger was incubated in different temperature degrees $(20,25$, $30,35,4045,50){ }^{\circ} \mathrm{C}$ to find the optimum incubation temperature for enzyme production, then the inoculation has done with the medium sugar cane (5 gm), corn steep liquor (5 $\mathrm{ml})$ and $\mathrm{pH} 5.0$ with $10^{6}$ spores $/ \mathrm{ml}$ of selected A. niger, the culture was incubated at $30{ }^{\circ} \mathrm{C}$ and checked every day for 5 days to estimate enzyme activity, protein concentration and specific activity for inulinase.

Mixed culture of $A$. niger and Kluyveromyces marxianus: Inulinase production medium was inoculated with three type of single and mixed inoculum at optimum conditions according to the method described by Ongen-Baysal and Sukan [10], After incubation of $30{ }^{\circ} \mathrm{C}$ for 96 hours, inulinase activity and protein concentration were determined.

\section{Results and Discussions:}

Semi-quantitative screening of inulinase producing isolates:

In order to examine the most efficient isolate for inulinase production, all fungal isolates of Aspergillus niger were recultured on the medium described by Kumar et $a l$. [8]. The culture was incubated for 4 days, at $30{ }^{\circ} \mathrm{C}$. Results showed different efficiencies in inulinase production. Inulin hydrolysis appear as clear zone around fungal colony. The most efficient isolate produces the wider clearance zone as in table (1). 
Table (1): The clearance zone ratios of $A$. niger isolates.

\begin{tabular}{|c|c|c|c|}
\hline Isolates & $\begin{array}{c}\text { Clearance zone } \\
\text { ratios }\end{array}$ & Isolates & $\begin{array}{c}\text { Clearance zone } \\
\text { ratios }\end{array}$ \\
\hline AN1 & 1.20 & AN16 & 1.05 \\
\hline AN2 & 1.10 & AN17 & 1.30 \\
\hline AN3 & 1.20 & AN18 & 1.40 \\
\hline AN4 & 1.60 & AN19 & 1.70 \\
\hline AN5 & 1.40 & AN20 & 1.95 \\
\hline AN6 & 1.20 & AN21 & 1.80 \\
\hline AN7 & 1.50 & AN22 & 1.23 \\
\hline AN8 & 1.20 & AN23 & 1.10 \\
\hline AN9 & 1.10 & AN24 & 1.40 \\
\hline AN10 & 1.30 & AN25 & 1.50 \\
\hline AN11 & 1.50 & AN26 & 1.20 \\
\hline AN12 & 1.17 & AN27 & 1.21 \\
\hline AN13 & 1.20 & AN28 & 1.26 \\
\hline AN14 & 0.90 & AN29 & 1.30 \\
\hline AN15 & 1.60 & AN30 & 1.20 \\
\hline
\end{tabular}

\section{Optimization of inulinase production:}

Optimum carbon source: Four carbon sources were tested for their efficiency in inulinase production. These sources were leek, onion, garlic and sugar cane (figure 1). The highest activity is shown in sugar cane with specific activity $112 \mathrm{U} / \mathrm{mg}$, while leek, garlic and onion showed specific activities as follows $24.15 \mathrm{U} / \mathrm{mg}, 86.1$ $\mathrm{U} / \mathrm{mg}$ and $87.35 \mathrm{U} / \mathrm{mg}$ respectively. This indicates that sugar cane is the most efficient source for inulinase production from A. niger AN2O. These results were similar to the results of Ettalibi and Baratti [11] who proved that selection of efficient media for inulinase production from Aspergillus ficuam depends on changing the media components, while Mazutii et al.,[12] found that the best medium for inulinase production from Kluyveromyces marixianus was sugar cane bagasse with corn steep liquor. Saber and El-Nagger [13] compared inulinase productivity from cultivation of Aspergillus taamarii different carbon sources included pure sources (glucose, maltose and inulin) and natural sources (Jerusalem artichoke, beetroot and chicory). They found that natural sources gave the highest activity among pure carbon sources where chicory gave $240.8 \mathrm{U} / \mathrm{mg}$, while pure inulin gave $220.2 \mathrm{U} / \mathrm{mg}$.

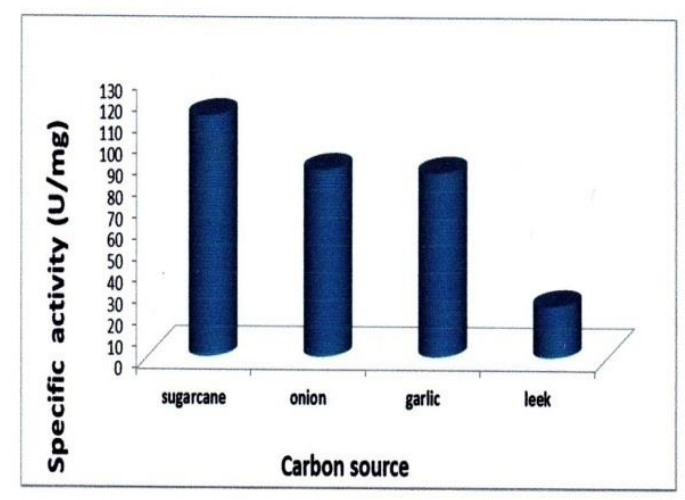

Fig.(1): The Effect of carbon source on inulinase production from local isolate $A$. niger $\mathrm{AN20}$, incubation for 4 days at $30^{\circ} \mathrm{C}$.

Moisturizing solution: To determine the best moisturizing solution for inulinase production, four different solutions A (Yeast extract, $\mathrm{MnSO}_{4}$, $\mathrm{K}_{2} \mathrm{HPO}_{4}$ and corn steep liquor), $\mathrm{B}$ $\left(\mathrm{NH}_{4} \mathrm{NO}_{3}, \quad \mathrm{MnSO}_{4}, \quad\right.$ Soya been, $\mathrm{K}_{2} \mathrm{HPO}_{4}$ and Distilled water), $\mathrm{C}$ (corn steep liquor) and D (Distilled water as a control treatment) were tested. Solution A gave the highest specific activity $124 \mathrm{U} / \mathrm{mg}$, while $B$ and $C$ gave $93.7 \quad \mathrm{U} / \mathrm{mg}$ and $61 \quad .8 \mathrm{U} / \mathrm{mg}$ respectively. Distilled water gave very low specific activity $33.4 \mathrm{U} / \mathrm{mg}$. These results prove that the highest specific activity of inulinase produced from $A$. niger AN2O, was obtained from the solution A (figure 2). Viswanathan and Kulkarni [14] found that the best moisturizing solution is corn steep liquor in presence of kuth root powder as source for inulinase production from A. niger with $92.4 \mathrm{U} / \mathrm{mg}$ specific activity. Kango [15] found that the use of yeast extract as nitrogen source with presence of dandelion root extract as carbon source was the best source for inulinase production from $A$. niger. 


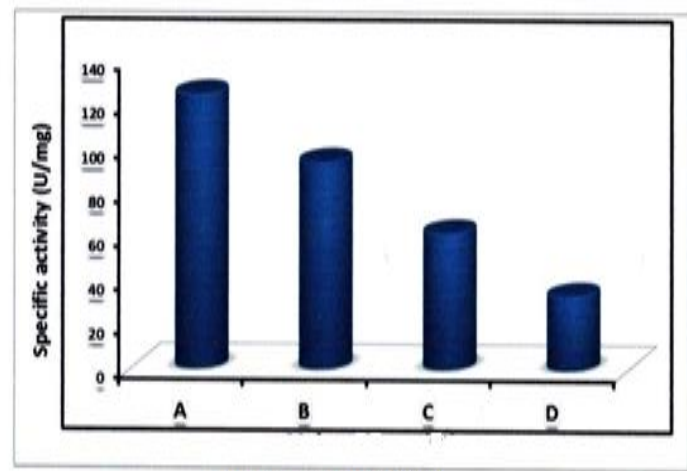

Moisturizing Solution $5 \mathrm{gml}$

Fig. (2): The Effect of different moisturizing solutions on inulinase production from local isolate $A$. niger AN20,using sugar cane, incubation for 4 days at $30^{\circ} \mathrm{C}$, pH 5. A.Yeast extract, $\mathrm{MnSO}_{4}, \mathrm{~K}_{2} \mathrm{HPO}_{4}$ and corn steep liquor. $\mathrm{B}$. $\mathrm{NH}_{4} \mathrm{NO}_{3}$, $\mathrm{MnSO}_{4}$, Soya been, $\mathrm{K}_{2} \mathrm{HPO}_{4}$ and Distilled water. C. Corn steep liquor. D. Distilled water.

\section{Moisture ratio:}

Five gm of sugar cane was moisten with different volumes of corn steep liquor containing yeast extract, $\mathrm{MnSO}_{4}$ and $\mathrm{K}_{2} \mathrm{HPO}_{4}$. These treatments were tested to select the optimum moisture ratio for inulinase production. The best moisture ratio was 5:5 (w/v) which gave specific activity $152.6 \mathrm{U} / \mathrm{mg}$ while 5:10, 5:15 and 5:20 ratios gave 121.8, 95.8 and 93.3 respectively (Figure 3). Mazutii et al. [12] found that the optimum moisture ratio for inulinase production from $K$. marixianus was $65 \%$.

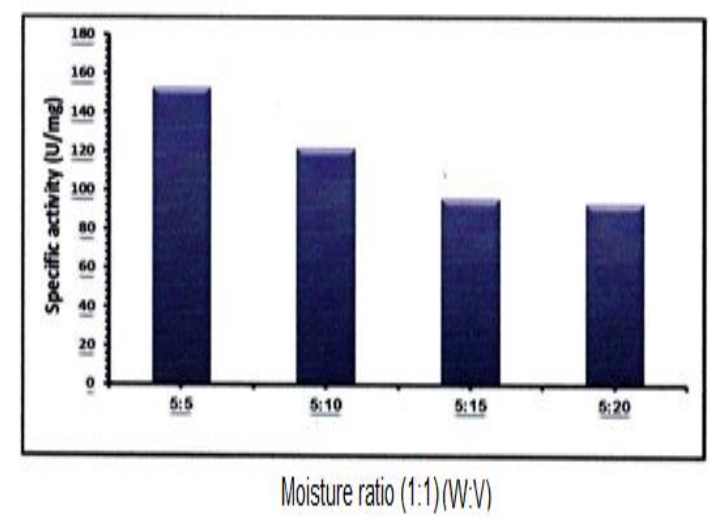

Fig. (3): The Effect of moisture ratio on inulinase production from local isolate $A$. niger AN20,using sugar cane, incubation for 4 days at $30^{\circ} \mathrm{C}$, pH 5.

Most of solid substrates used in solid state fermentation are insoluble in water, therefore water will have to be absorbed onto the substrate particles, which can be used by the microorganisms for growth and metabolic activity (Pandey) [16]. Thus, it is concluded that the degree of hydration of the substrate plays an important role in the growth of the fungi and subsequently the enzyme production. Water causes the swelling of the substrate and facilitates good utilization of substrates by the microorganisms. Increasing moisture level is believed to have reduced the porosity of substrate, thus limiting the oxygen transfer into the substrate (Raimbault and Alazard, 1980 ; Moat et al.,) [17, 18]. Likewise, a lower moisture ratio leads to reduced solubility of the nutrients of the solid substrate, lower degree of swelling and a higher water tension (Ikasari and Mitchell) [19].

Initial pH of production media: The specific activity for inulinase was estimated after incubation to determine the optimum $\mathrm{pH}$ and the results were illustrated in figure (4), the optimum $\mathrm{pH}$ for enzyme activity was 5.0 because gave high specific activity $154.9 \mathrm{U} / \mathrm{mg}$, while $\mathrm{pH} 4,6,7,8,9$ 
gave 134.6, 130.1, 104.0, 88.6 and 74.3 U/mg respectively. The results of Ertan and Ekinci [20] proved that the optimum $\mathrm{pH}$ for inulinase productivity from A. niger is 5.0. Gouda [21] found the optimum $\mathrm{pH}$ for inulinase productivity from A. fumigatus was 6 which gave activity $35.56 \mathrm{U} / \mathrm{mg}$. Fungi generally prefer slightly acid conditions and therefore tend to dominate bacteria when these prevail. The reason for the growth rate falling away either side of the optimum value is again due to alterations in threedimensional protein structure (Moat $e t$ al.,) [18]. The $\mathrm{pH}$ affects in enzyme production because of its role in the solubility of medium substrates and its effect on the ionization of the substrate and it's availability for the fungal growth. Moreover the $\mathrm{pH}$ affects the productivity and enzyme stability.

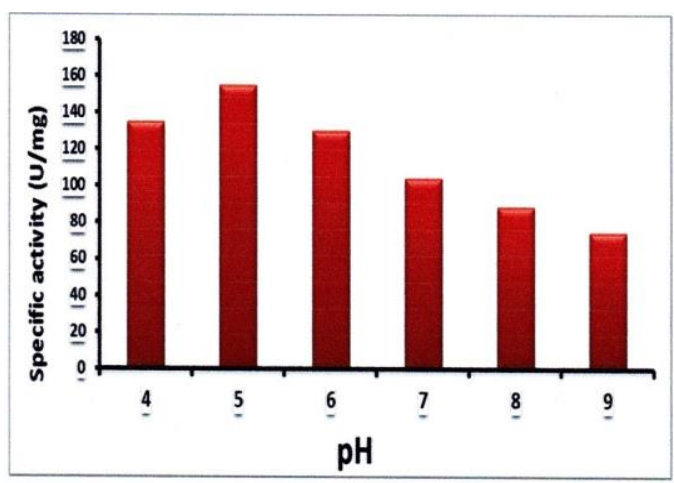

Fig. (4): The Effect of $\mathrm{pH}$ on inulinase production from local isolate $A$. niger AN20, using sugar cane, with 5:5 moisture, incubation for 4 days at $30^{\circ} \mathrm{C}$.

Incubation temperature: The culture which consist of the medium(sugar cane, corn steep liquor), with $\mathrm{pH}$ 5.0, inoculated with 106 spores of $A$. niger AN20 was incubated in different temperature degrees $(20,25,30,35$, $40,45,50){ }^{\circ} \mathrm{C}$ to find the optimum incubation temperature for enzyme productivity. The results in Figure (5) show that the optimum incubation temperature is $30{ }^{\circ} \mathrm{C}$ which gave the specific activity of $121.5 \mathrm{U} / \mathrm{mg}$. Lower and higher temperatures decreases the specific activities because of the thermal effects of these temperatures on the microorganism growth and on the enzymatic reaction rate inside the cells which reflects on the vital creation of the enzyme. Darija et al. [22] found that $30-33{ }^{\circ} \mathrm{C}$ is the optimum temperatures for inulinase production from A. ficuum, while Nandogobal and Kumari [23] referred to the preference of the high incubation temperature because it has advantages in increasing the solubility of inulin in addition to prevention of microbial contamination in culture medium, where they found that $50{ }^{\circ} \mathrm{C}$ is the optimum temperature for inulinase production from $A$. niveus and Penicillium purpurogenum.

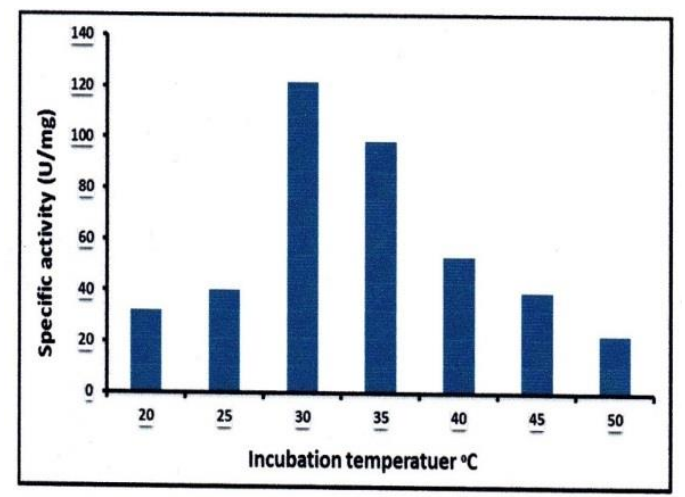

Fig.(5): The Effect of incubation temperature on inulinase production from local isolate $A$. niger AN20, using sugar cane pH 5, with 5:5 moisture, incubation for 4 days.

Temperature is one of the important parameters that determine the success of SSF system. Kheng and Omar [24] results indicated that the enzyme production corresponded closely to the growth of the fungus, and the optimum temperature for inulinase production from A. niger is similar to the optimum temperature for the growth of the fungus. This observation was in agreement with those reported by Sudgen and Bhat, and Biswas et al. 
$[25,26]$, who showed that the highest inulinase activities were obtained at temperatures that were optimum for the growth of the fungi in solid-state fermentation.

\section{Incubation period:}

The results in figure (6) show the effect of incubation period 24-120 hrs. on inulinase production from $A$. niger AN20. The highest specific activity was at 4 days of incubation 140.5 $\mathrm{U} / \mathrm{mg}$ and then became $76.3 \mathrm{U} / \mathrm{mg}$ after 5 days of incubation. These results corresponds to the studies of Kango, and Gouda [15, 21] who found that 4 days is the optimum incubation period for inulinase production from $A$. niger and A. fumigatus.

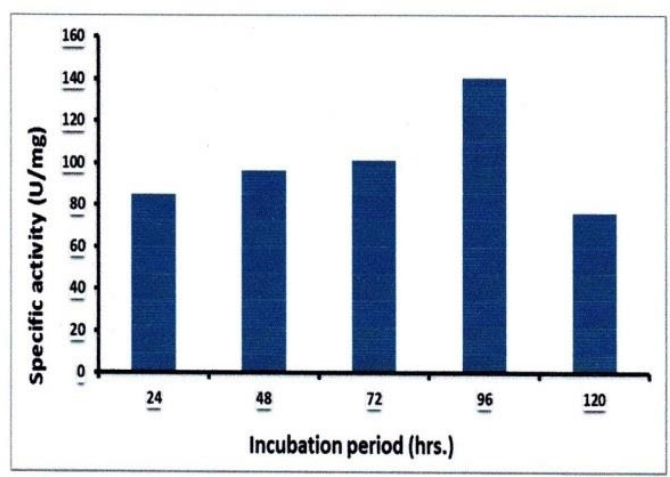

Fig. (6): The Effect of incubation period on inulinase production from local isolate $A$. niger AN20, using sugar cane pH 5, with 5:5 moisture, incubation at $30^{\circ} \mathrm{C}$.

The specific activity of enzyme was decreased after $96 \mathrm{hrs}$. of incubation (figure 6).

The enzyme production decrease after 96 hrs. of incubation is due to The production of reducing sugar such as glucose and fructose in culture medium which may lead to repression of inulinase production because these sugars are more readily carbon source than inulin (Vandamme and Derycke,) [27]. This decrease in enzyme production occurred as a result of the reduce in nutrients of the medium and as a result of accumulation the catabolic repression of enzyme (Kheng and Omar,)[24].

The Effect of mixed culture $A$. niger AN20 and $K$. marxianus on inulinase production:

To examine the inulinase productivity of $A$. niger AN20 and $K$. marxianus, they were mixed together according to the method described by Ongen-Baysal and Sukan [10]. The results are illustrated in figure [7], and shows that niger AN20 culture gave the highest specific activity of $153 \mathrm{U} / \mathrm{mg}$, while mixed culture gave $141 \mathrm{U} / \mathrm{mg}$, and $K$. marxianus culture gives $86 \mathrm{U} / \mathrm{mg}$. This result of $A$. niger culture agrees with Ertan et al [1].

It is known that the synthesis of inulinase are controlled by the same mechanism in both organisms but the specific growth rate of organisms are found to be different with $K$. marxianus $\left(0.53 \mathrm{hr}^{-1}\right)$ and $A$. niger $\left(0.11 \mathrm{hr}^{-1}\right)$. Thus both organisms compete for the same carbon source. Therefore inoculums size and time of addition $K$. marxianus might be critical factor in the optimization of inulinase production by mixed culture (OngenBaysal and Sukan,)[10]. Sukan et al [28] found in his study on hydrolysis of jerusalim artichoke extract by inulinase from monocultures and mixed cultures of A. niger AN20 and $K$. marxianus that $A$. niger alone gave specific activity $122 \mathrm{U} / \mathrm{mg}, K$. marxianus $50 \mathrm{U} / \mathrm{mg}$, while mixed culture gave $83 \mathrm{U} / \mathrm{mg}$. 


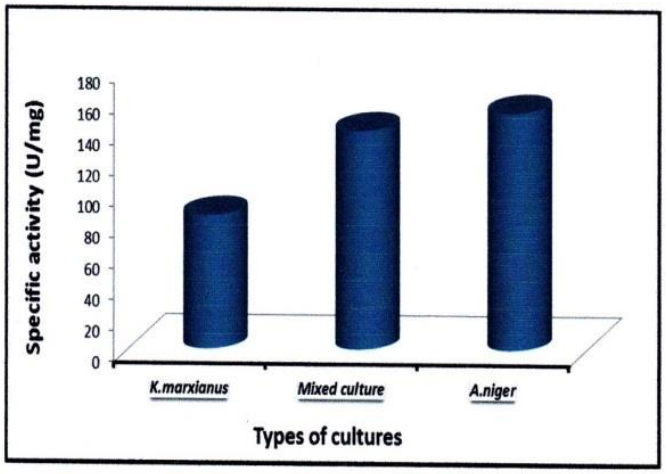

Fig. (7): Inulinase productivity from $A$. niger AN20, $K$. marxianus and mixed culture $A$. niger $\mathrm{AN20}+K$. marxianus, using sugar cane, with 5:5 moisture, incubation for 4 days at $30^{\circ} \mathrm{C}$ at $\mathrm{pH} 5$.

\section{References:}

1.Ertan, F. ; Ekinci, F. and Aktac, T. 2003. Production of inulinase from Penicillium spinulosum, Kluyveromyces marxianus, Aspergillus parasiticus NRRL2999 and Trichoderma viride. Pakistan $\mathrm{J}$ Biol Scien. 6(15): 1332-1325.

2.Roze, L.V.; Beaudrv, R. M.; Arthur, A. E.; Calvo, A. M. and Linz, J. E. 2007. Aspergillus volatiles regulate aflatoxin synthesis and asexual sporulation in Aspergillus parasiticus. Appl Environ Microbiol. 73(22):72687276.

3. Perfect, J. R.; Cox, C. M. and Lee, J. V. 2001. The impact of culture isolation of Aspergillus species: a hospital-based survey of aspergillosis. Clin Infect Dis. 33: 1824-1833.

4. Weir, E. 2000. Production of Industrial Enzymes in Fermentation. J. Biol. 5:213-224.

5. Mutanda, T.; Wilhelmi, B. S. and Whiteley, C. G. 2008. Response surface methodology: Synthesis of inulo-oligosaccharides with an endoinulinase from Aspergillus niger. Enzyme and Microbial. Tech. 43:362-368.
6. Miller, G.L. 1959. Use of dinitrosalicylic acid reagent for determination of reducing sugar, Anal. Chem. 31: 426-428.

7. Bradford, M. 1976. A rapid and sensitive method for the quantitation of microgram quantities of protein using the principle of protein-dye binding. Anal. Biochem., 72 : 248-254.

8. Kumar, G. P.; Kunamneni, A.; Prabhakar, T. and Ellaiah, P. 2005. Optimization of process Parameters for the production inulinase from a newly isolated Aspergillus niger AUP1. World $\mathrm{J}$ Microbiol and Biotechnol. 21(8): 1359-1361.

9. Skowronek, M. and Fidurek, J. 2006. Purification and properties of extracellular endoinulinase from Aspergillus niger 20 OSM. Food technol. Biotechnol. 44(1): 53-58.

10. Ongen-Baysal, G. and Sukan, S. S. 2008. Production of inulinase by mixed culture of Aspergillus niger and Kluyveromyces marxianus. Biotechnol. Lett. 18(12): 14311434.

11. Ettalibi, M. and Baratti, J. C. 1987. Purification, properties and comparison of invertase, exoinulinase and endoinulinase of Aspergillus ficuam. Appl Microbiol Biotechnol. 26: 13-20.

12. Mazutii, M.; Bender, J. P.; Treichel, H. and Di Luccio, M. 2006. Optemization of inulinase production by soild state fermentation using sugarcane bagasse as substrate. J. Biotechnol. 12: 1123-1131.

13. Saber, W. I. A.; El-Naggar, N. E. 2009. Optimization of fermentation conditions for the biosynthesis of inulinase by the new source; Aspergillus tamarii and hydrolysis of some inulin containing agrowastes. J Biotechnol. 8: 425433. 
14. Viswanathan, P. and Kulkarni, P. R. 1995. Saussurea lappa (kuth) as a new source of inulin for fermentative production of inulinase in laboratory stirred fermenter. Bioresource Technol. 52: 181-184.

15. Kango, N. 2008. Production of inulinase using tap roots of dandelion (Taraxacum officinale) by Aspergillus niger. $\mathrm{J}$ food Eng. 85:473-478.

16. Pandey, A. 1992. Recent process developments in solid-state fermentation. Process Biochem J. 27:12-17.

17. Raimbault, M. and Alazard, D. 1980. Culture method to study fungal growth in solid fermentation. Eur. J. Appl. Microbiol. Biotechnol. 9: 199-209.

18. Moat, A. G.; Foster, J. W. and Spector, M. P. 2002. Microbial Physiology. $4^{\text {th }}$ ed. Wiley-Liss, Inc., New York. 1: 1-28.

19. Ikasari, L. and Mitchell, D. A. 1994. Protease production by Rhizopus oligaosporus in solid-state fermentation. Appl. Microbiol. Biotechnol. 10: 320-324.

20. Ertan, F. and Ekinci, F. 2002. The production of inulinase from Alternaria alternata, Aspergillus niger and Trichoderma harzianum. J Marmara from pure and appl scien. 18: 7-15. Marmara University printed in Turkey.

21. Gouda, M. K. 2002. Some properties of inulinase from Aspergillus fumigants. Pakistan $\mathrm{J}$ Biological Scienc. 5: 589.593.

22. Darija, V.; Zelimir, K.; Santos, M. P. A. and Francisco, N. 2002.
Optimization of inulinase production by Kluyveromyces bulgaricus. Food technol Biotechnol. 40: 67-73.

23. Nandagobal, S. and Kumari, B. D. R. 2006. Enhancement of Inulinase production from chicory and Rhizosphere soil. American Eurasion J. Agric. \& Environ. Sci. 1 (3): 225-228.

24. Kheng, P. P. and Omar, I. 0. 2004. Inulinase production by a local fungal isolate. Aspergillus niger USM AI 1 via solid state fermentation using palm kernel cake (PKC) as substrate. Songklanakarin J. Sci. Technol. 27(2): 326-336.

25. Sudgen, C. and Bhat, M. K. 1994. Cereal straw and pure cellulose as carbon sources for growth and production of plant cell wall degradation enzymes by Sporotrichum thermophile. World J Microbiol Biotechnol. 10: 444-451.

26. Biswas, S. R.; Jana, S. C.; Mishra, A.K. and Nanda, G.1990. Production, purification and characterization of xylanase and inulinase from a hyperxylanolytic mutant of Aspergillus orchraceus. Biotechnol. Bioeng. 35: 244-25 1.

27. Vandamme, E. J. and Derycke, D. G. 1983. Microbial inulinases: fermentation process, properties and applications Adv. Appl. Microbiol. 29: 139-176.

28. Sukan, S. S.; Ongen-Baysal, G. and Vassilcv, N. 2009. Production inulinase from monocultures and mixed cultures of Aspergillus niger and Kluyveromyces marxianus. Biotechnol. Lett. 16 (3): 275-280. 


\title{
Aspergillus niger تحديد الظروف المثلى لأنتاج أنزيم الأنيولينيز من فطرات المطة بوساطة تخمرات الحالة الصلبية
}

\author{
غازي منعم عزيز
}

بهاء نظام عيسى

زينب وليد عبد الأمير
قسم التقنيات الأحبائية- كلية العلوم/ جامعة بغداد
*قسم الثؤون العلمية/ رئاسة جامعة بغداد التمادة

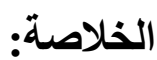

غربلت قابلية ثلاثون عزلة محلية من الفطر Aspergillus niger على انتاج انزيم الأنيولينيز بأستعمال الوسط

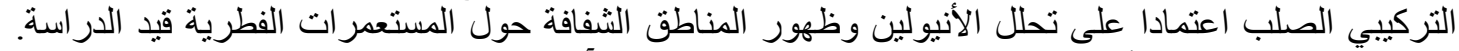

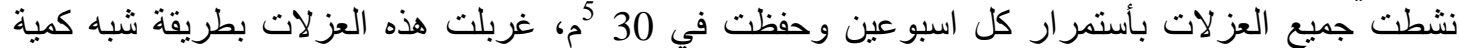

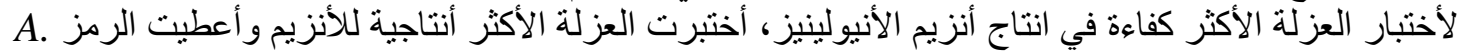
niger AN20

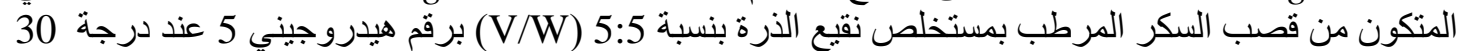

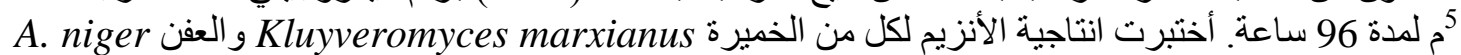

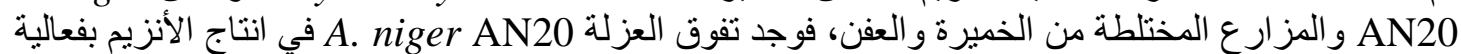
نو عية مقدار ها 153 وحدة/ملغم بروتين مقارنة مع استعمال الخميرة حيث أعطت 86 وحدة وحدة/ملغم بروتين.

Kluyveromyces marxianus .Aspergillus niger ، الكلمات المفتاحية: الأنيولينيز 